\title{
SOCIAL RESPONSIBILITY EFFECT ON CLIENT - ORIENTATION REGARDING TO MEDIATORY ROLE OF JOB SATISFACTION AND REALIZED ORGANIZATIONAL COMMITMENT BY WORKERS
}

\author{
Mahdi Ghorbanzad Kohnesari \\ Department of public Management, Bandar e Anzali Branch, Islamic Azad University, Gilan, Iran \\ Morteza Hazraty \\ Mhazraty2006@yahoo.com
}

\begin{abstract}
Present research follows to study social responsibility effect on client-orientation regarding to mediatory role of job satisfaction and realized organizational commitment by Guilan Melli bank workers . Present research statistical case is 315 Guilan Melli bank branches workers in iran to collect data and sampling method is classifying random. Using tool is Chronbach alpha for standard stability and response spectrum is 5 points likert. Questionnaire has made in field method and research is descriptive- analytical. To obtain data has used Liserl method. Deductive software has used structural equations modeling and data analysis showed that social responsibility eas effective directly and through job satisfaction and organization commitment on client tendency among workers.
\end{abstract}

Keywords: social responsibility, client-orientation, job satisfaction, organizational commitment

\section{INTRODUCTION}

Client-orientation causes positive financial results for organization as a marketism dimension. This process from client tendency will result in clients satisfaction and loyalty. Workers tendency subject to supply client needs refers to job culture. Tendency to client is the main dimension in each firm. It seems that client-orientation culture creating is nicissary to success organization and increase competitive advantage. Client-orientation results in client service act improvement (Lee et al, 2013). Client service act improvement leads to higher financial act, also high service levels result in higher rate of client conservation that its result is more sell and higher market share that are affected by different variables. Song et al (2015) in a research showed that social responsibility results in organization client-orientation. They showed that social responsibility through a process and organizational commitment and job satisfaction result in client-orientation. Many organizations serve social responsibility as the most important strategy to reach stable competitive advantage. Commitment has defined as need to conserve a continouse relation, and a relation creates on the basis of mutual trust and commitment. Organizational commitment is showing workers extra try to obtain organizational purpose.

Organizational commitment is a psychological mood description that shows individual wants to stay at organization (Asiedu et al, 2014). Commitment is from interest and loyalty to work and strong believe to organizational values (Salehi et al, 2014). In organization social responsibility and client-orientation, organizational commitment will result in workers job satisfaction. Job satisfaction is a positive sense from job evaluation or its different dimensions (Russo \& Buonocore, 2012). Regarding to above cases and this point that today as increasing banks number and financial instituations, attracting new clients forces costs for bank and in other hand researches have shown that present clients conserve cost is less than new clients attraction, so researches to rise tendency to client and its effective factors are necessary, because client- orientation fially results in increasing clients satisfaction and loyalty and improving banks act. The 
main research question is as follow: Is affective Melli bank social responsibility on tendency to client by workers job satisfaction and organizational commitment.

\section{RESEARCH THEORETICAL FRAME}

Brammer et al, (2007) and also Turker (2009) studied workers realization of social responsibility and organizational commitment. They indicated that workers realization of organization social responsibility has an important role in organizational commitment. In castka \& Ba lzarova view (2010) social responsibility is continose commitment for moral behavior and individuals and their family life quality improvement, society improvement in wider scale (Maghighatian et al, 2013).

Organizational commitment is an important job and organizational view that during past years had attracted many researchers of organizational and psychological behavior especially social psychology. This attitude has changed in 3 ago decades (Khoshnood, 2011). Emotional dependency is a stable factor that relates individuals to organization that organizational commitment is a form of this emotional dependency (Thoma, 2015). Related to organizational commitment effect on job satisfaction should refers to Vandenberg \& Lance (1992) that showed workers organizational commitment could be a cause to create job satisfaction. Workers job satisfaction as desired emotional status of job evaluation has defined to obtain job values and / or simple access to them (Jung \& Yoom, 2013). Bateman and stasser (1984) said that during time, organizational commitment results in job satisfaction. Nam a sivayam and Zhao (2007) showed that organizational commitment has direct effect on workers job satisfaction. Related to job satisfaction effect on client-orientation Hoffman and Ingram (1992) said that job satisfaction could result in client-orientation behaviors. Client-orientation is a firm enough realization of its buyers to create higher value for them (Alteren \& Tudoran, 2015). Lee et al, (2013) also verified job satisfaction positive effect on client - orientation (Song et al, 2015). Regarding to mentional cases and past researches results such as song et al, (2015) research model is as follow:

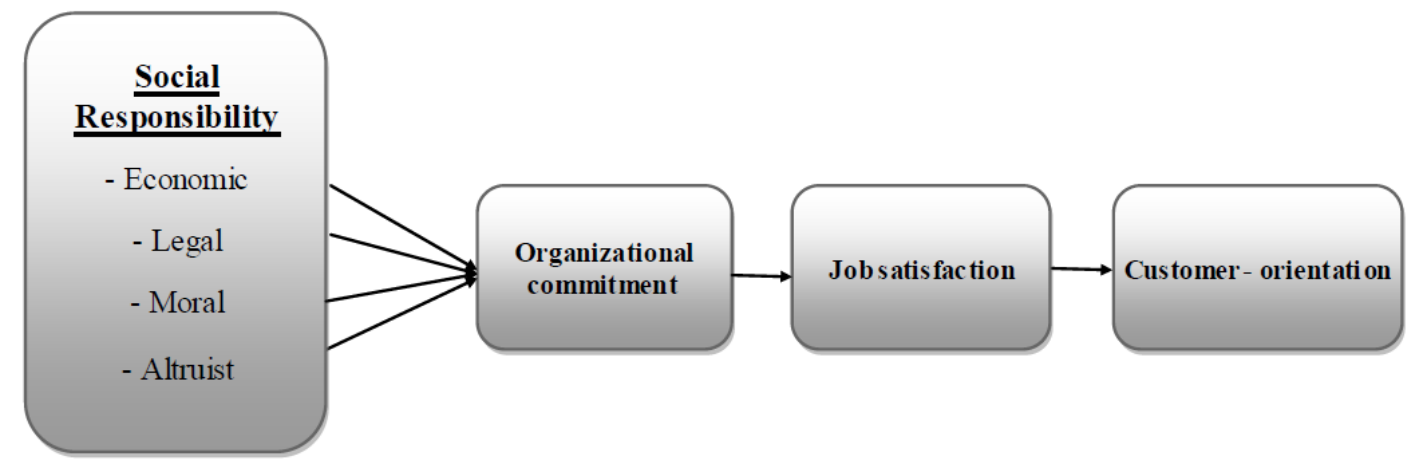

Figure 1: Research teorethical model (Song et al, 2015)

Regarding to theoretical frame and defined aims, research hypotheses are as follow :

1- Social responsibility economic dimension affects on organizational commitment .

2- Social responsibility legal dimension affects on organizational commitment .

3- Social responsibility moral dimension affects on organizational commitment .

4- Social responsibility altruist dimension affects on organizational commitment . 
5- Organizational commitment affects on job satisfaction .

6- Job satisfaction affects on tendency to client .

\section{METHODOLOGY}

Present research aim is practical and its conducting method is description. This research method is correlational and data collection is field for Guilan Melli bank workers . Total workers number is 1400 in sampling . Research statistical community is classifying random and among workers. Regarding to above formula case mass is 310 ones. In this research used questionnaire to use Melli bank workers view and attitudes. Questionnaire has two parts that first part includes individual information and second part has expert questions.

Table 1: Questionnaire questions table

\begin{tabular}{|c|c|}
\hline Dimensions & Reference \\
\hline Social responsibility & \\
\cline { 1 - 1 } Organizational commitment & \multirow{2}{*}{ Song et al. 2015 } \\
\cline { 1 - 1 } Job satisfaction & \\
\hline Customer-orientation & \\
\hline
\end{tabular}

In this research to determine questionnaire stability emphasized on questions coincidence and used Chronbach alpha for any varuable. To compute stability coefficient used SPSS that firstly a case includes 30 questionnaires and then calculated Chronbach alpha.

Table 2: Chronbach alpha related to questionnaire questions stability

\begin{tabular}{|l|c|}
\hline \multicolumn{1}{|c|}{ Variable } & Cronbach Alfa \\
\hline Social responsibility & 0.905 \\
\hline Organizational commitment & 0.856 \\
\hline Job satisfaction & 0.873 \\
\hline Customer-orientation & 0.893 \\
\hline
\end{tabular}

Table 3: Research variables description

\begin{tabular}{|c|c|c|c|c|c|c}
\hline Variables & $\mathrm{N}$ & Min & Max & Mean & S. D. & Std. Error Mean \\
\hline Economical responsibility & 315 & 1.67 & 5 & 3.5101 & 0.74452 & 0.554 \\
\hline legal responsibility & 315 & 1.25 & 5 & 3.7079 & 0.74921 & 0.561 \\
\hline moral responsibility & 315 & 1 & 5 & 3.7175 & 0.84977 & 0.722 \\
\hline altruist responsibility & 315 & 1.25 & 5 & 3.5556 & 0.77691 & 0.604 \\
\hline Organizational commitment & 315 & 1 & 5 & 3.7194 & 0.72742 & 0.529 \\
\hline Job satisfaction & 315 & 1 & 5 & 3.5113 & $79647 / 0$ & 0.634 \\
\hline Customer-orientation & 315 & 1 & 5 & 3.7270 & 0.69866 & 0.488 \\
\hline
\end{tabular}

\section{NORMALITY TEST}

Table 4: Klomogroph-Smirnoph test for research variable .

\begin{tabular}{|c|c|c}
\hline Variable & Significant level & The Test Statistic \\
\hline Economical responsibility & 0.521 & 0.814 \\
\hline Legal responsibility & 0.053 & 1.498 \\
\hline Moral responsibility & 0.724 & 0.692 \\
\hline Altruist responsibility & 0.488 & 0.835 \\
\hline
\end{tabular}




\begin{tabular}{|c|c|c}
\hline Organizational commitment & 0.258 & 1.011 \\
\hline Job satisfaction & 0.214 & 1.057 \\
\hline Customer-orientation & 0.318 & 0.958 \\
\hline
\end{tabular}

Regarding to table (4) observe that obtained meaningful level for Kolmogroph - Smirnoph test is up to $0 / 05$ and research variables have normal distribution.

Table 5 - Research variable $\mathrm{t}$ - test results Regarding to $\mathrm{t}$ - test results in table ( 5 ) observe that research variables mean is more than certain limit also regarding to table observe that the most mean is fore tendency to client and at least for economic responsibility variable.

Table 5: Result of T-test

\begin{tabular}{|c|c|c|c|c|c}
\hline variable & $\mathrm{T}$ & Mean & $\mathrm{T}$ & Std. Error Mean & Sig. (2-tailed) \\
\hline Economical responsibility & 315 & 3.5101 & 12.159 & 0.74452 & 0.000 \\
\hline legal responsibility & 315 & 3.7079 & 16.77 & 0.74921 & 0.000 \\
\hline moral responsibility & 315 & 3.7175 & 14.985 & 0.84977 & 0.000 \\
\hline altruist responsibility & 315 & 3.5556 & 12.691 & 0.77691 & 0.000 \\
\hline Organizational commitment & 315 & 3.7194 & 17.552 & 0.72742 & 0.000 \\
\hline Job satisfaction & 315 & 3.5913 & 13.176 & $79647 / 0$ & 0.000 \\
\hline Customer-orientation & 315 & 3.7270 & 18.468 & 0.69866 & 0.000 \\
\hline
\end{tabular}

\section{DEDUCTIVE TEST}

Table 6: Variables subject in model

\begin{tabular}{|c|c|}
\hline Variable & Symbol \\
\hline Economical responsibility & ECCSR \\
\hline legal responsibility & LCCSR \\
\hline moral responsibility & ETCSR \\
\hline altruist responsibility & PCSR \\
\hline Organizational commitment & OC \\
\hline Job satisfaction & JS \\
\hline Customer-orientation & CO \\
\hline
\end{tabular}

\section{RESEARCH MODEL IN MEANINGFUL NUMBERS}




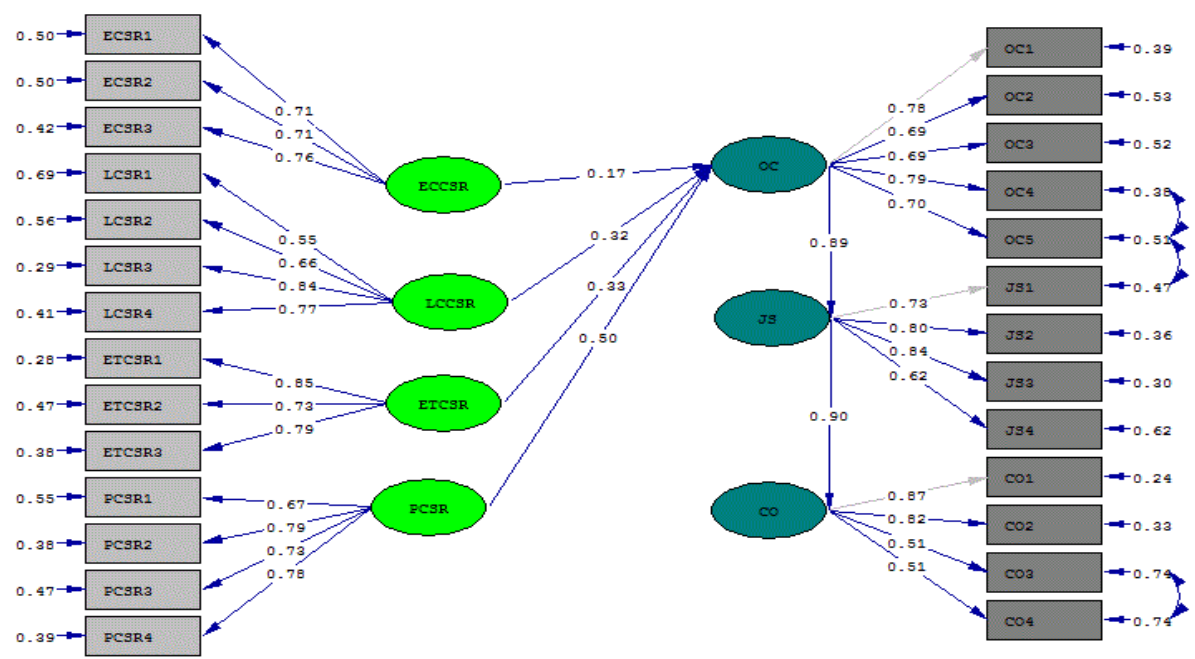

Chi-Square $=833.43, \mathrm{df}=309, \mathrm{P}-\mathrm{value}=0.00000, \mathrm{RMSEA}=0.074$

Using this could find meaningful relationship between research variables . In this status numbers are meaningful that is out of $(-1 / 96,1 / 96)$. It means it's meaningless between 1/96, $-1 / 96$.

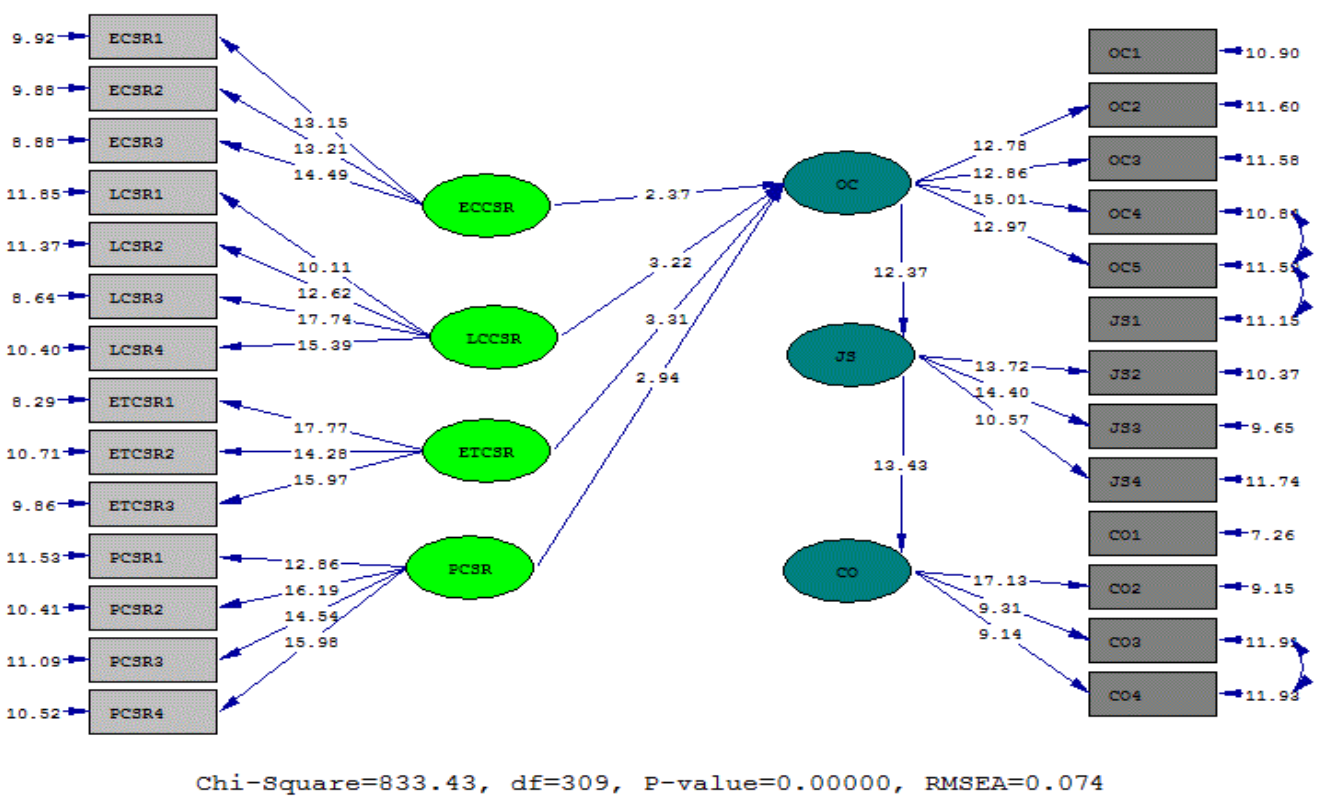

Study of model test indirect: At follow study tested model indirect effect.

Table 7: indirect way coefficient

\begin{tabular}{|c|r|}
\hline Indirect coefficient & \multicolumn{1}{|c|}{ Path } \\
\hline 0.14 & Customer-orientation $\leftarrow$ job satisfaction $\leftarrow$ Commitment $\leftarrow$ economical \\
\hline 0.27 & Commitment $\leftarrow$ legal responsibility \\
\hline 0.26 & Commitment $\leftarrow$ moral responsibility \\
\hline 0.40 & Commitment $\leftarrow$ altruist responsibility \\
\hline
\end{tabular}

Submit Date: 11.06.2016, Acceptance Date: 27.07.2016, DOI NO: 10.7456/1060AGSE/066 
As above table altruist social responsibility indirect effect through organizational commitment and job satisfaction on tendency to client is more than others .

\section{CONCLUSION AND SUGGESTIONS}

At first hypothesis studies social responsibility economic dimension effect on organizational commitment, results showed that its effect is positive and meaningful, so in $95 \%$ reliability verified first hypothesis. Its effect rate on organizational commitment is 0.17 . This is accordance to Song et al, (2015) results. At second hypothesis studies legal dimension. Results showed that it has positive and meaningful effect so in $95 \%$ verified second hypothesis. Its effect rate on organizational commitment is 0.32 . This result is accordance to Song et al.

At third hypothesis studies moral dimension. Results showed that moral dimension has positive and meaningful effect on organizational commitment. So in $95 \%$ reliability verifies third hypothesis. Its effect rate is 0.33 . This result is accordance to Song et al, (2015) results. At fourth hypothesis studies altruist dimension effect that results showed that its effect is positive and meaningful. So in $95 \%$ reliability verifies fourth hypothesis. Its effect rate is $50 \%$. This result is accordance to Song et al, (2015) results. At fifth hypothesis studies organizational commitment effect on job satisfaction. Results showed that it has positive and meaningful effect. So in $95 \%$ reliability verifies fifth hypothesis. Its effect rate is 0.89. This result is a accordance to Song et al, (2015). At sixth hypothesis studies job satisfaction effect on tendency to client. Results showed that reliability verifies sixth hypothesis. Its effect rate is $90 \%$. This result is accordance to Song et al, (2015), Lee et al, (2013) and Jafari and Mehrabian (2015) .

\section{REFERENCES}

Alteren, Gro \& Tudoran ,Ana Alina (2015), "Enhancing export performance: Betting on customer orientation, behavioral commitment, and communication" International Business Review N.25,PP:370381.

Asiedu, Michael et al.,(2014) " ORGANISATIONAL COMMITMENT AND CITIZENSHIP BEHAVIOUR: TOOLS TO IMPROVE EMPLOYEE PERFORMANCE; AN INTERNAL MARKETING APPROACH " European Scientific Journal, vol.10, No.4.pp:288-305.

Buckly M. R. ,D s.Beu,D. D. Frink (2001)»Ethical Issues in Human Resources Systems»,Human Resource Management Review,No.11,11-29.

Buket., Arikboga, F. Sebnem., (2015), " The Effects of Leader Behavior on Job Satisfaction: A Research on Technology Fast50 Turkey Companies ", Procedia - Social and Behavioral Sciences 195, 278 - 282.

Esen, E. (2013). The Influence of Corporate Social Responsibility (CSR) Activities on Building Corporate Reputation. Advances in Sustainability and Environmental Justice, 11, 133-150.

Freeman, I. \& Hasnaoui, A. (2011). "The meaning of corporate social responsibility: The vision of four nations", Journal of Business Ethics, 100 (3), pp. 419-443.

Fullerton, G. (2011). "Creating advocates: The roles of satisfaction, trust and commitment", Journal of Retailing and Consumer Services, 18 (1), pp. 92-100.

Galli,D., Elefanti, M., Valotti, G.(2013), " From Corporate To Shared Social Responsibility: Community Governance and Social Capital Creation Through Collaboration ",APPAM International Conference :Collaboration Among Government, Market, and Society: Forging Partnerships and Encouraging Competition, Fudan University, Shanghai, China, May, 26-27.

Guo-Chiquan and et al.,(2014)" How to calibratecon ventional market-oriented organizational culture in 21st century production-centered firms? A customer relationship perspective " Int. J.Production Economics ,no 156 ,pp:235-245

Hosseini M, Mehdizadeh Ashrafi A. [Identification of effective factors on organizational commitment.] Management Journal. 2010; 7(18): 9-16. Persian. 
Howard J. Klein, Heeman Park, (2015), " Organizational Commitment ", International Encyclopedia of the Social \& Behavioral Sciences (Second Edition), P 334-340.

Idar, R., and Mahmood, R. (2012). "Marketing orientation as mediator to entrepreneurial orientation and performance relationship: evidence from malaysian smes ", The 8th SMEs in a Global Economy Conference, Rising to the Global Challenge: Entrepreneurship and SMEs development in Asia, 227.

Imani Nojani, Masoumeh. et al , (2012), " The study on relationship between organizational justice and job satisfaction in teachers working in general ", special and gifted education systems, Procedia - Social and Behavioral Sciences 46, $2900-2905$.

Isa, S. M. (2012). Corporate Social Responsibility: What can we Learn from the Stakeholders?. ProcediaSocial and Behavioral Sciences, 65, 327-337.

Joo, M. Y., Jae, K. M., Seok, H. J., Joo, J. L. (2012). "The Effects Entrepreneurship and Market Orientation on Social Performance of Social Enterprise ". International Conference on Economics Marketing and Management, IPEDR Vol.28, IACSIT Press, Singapore, Vol 28, pp.60-65.

Jung, hyo sun \& yoon, hye hyun(2013)" Do employees' satisfied customers respond with an satisfactory relationship? The effects of employees' satisfaction on customers' satisfaction and loyalty in a family restaurant" International Journal of Hospitality Management, Volume 34, September 2013, pp:1-8.

Kiakajori, K. , \& Gafarnejad, A. \& Hoseinzadeh, S. A. A. (2010). " Explain the relationship between organizational culture and job satisfaction.", Journal of Executive Management, 2 (40), 87-108. (in Persian).

Kucukusta, D., Mak, A., \& Chan, X. (2013). Corporate social responsibility practices in four and five-star hotels: Perspectives from Hong Kong visitors.International Journal of Hospitality Management, 34, 1930 .

Lambert, Eric G., Hogan, Nancy L., Griffin, Marie L., (2007), "The impact of distributive and procedural justice on correctional staff job stress, job satisfaction, and organizational commitment", Journal of Criminal Justice 35, 644-656.

Lau h.c. \& m. a. Idris,(2005),»Soft foundations of the critical success factors ontqm implementation in Malaysia», TQM Magazine ,vol.13,no.4.pp515-52.

Lee.C, Song.H, Lee.H, Lee.S, Bernhard.B, (2013), "The impact of CSR on Casino employee's organizational trust, Job satisfaction, and customer orientation: A empirical examination of responsible gambling strategis", International Journal Hospitality Management, Vol. 33, pp. $406-415$.

Lee.C, Song.H, Lee.H, Lee.S, Bernhard.B, (2013), "The impact of CSR on Casino employee's organizational trust, Job satisfaction, and customer orientation: A empirical examination of responsible gambling strategis", International Journal Hospitality Management, Vol. 33, pp. 406 - 415.

Liu, Hefu,. Ke, Weiling,. Wei,Kwok Kee, Hua, Zhongsheng (2012), Effects of Supply Chain Integration and Market Orientation onFirm Performance: Evidence from China, International Journal of Operations \& ProductionManagement, Vol. 33, Iss: 3, p6.

Nordin, Norshidah, (2012), " Assessing Emotional Intelligence, Leadership Behaviour and Organizational Commitment in a Higher Learning Institution ", Procedia - Social and Behavioral Sciences 56 , 643 651.

Oyeniyi, $\mathrm{O}(2013)$, Organizational commitment and market orientation of Nigerian non-oil exporting companies, African Journal of Economic and Management Studies, Volume: 4, Issue:1, p1.

Pettenella, D., 2010. CSR: What it is, what issues it incorporates? What costs/benefits of implementation? In: United Nations Economic Commission for Europe, UNECE Workshop on Corporate Social Responsibility. Belgrade, Serbia, 13-14 April. Belgrad: UNECE.

Poddar ,Amit ., Ramana Madupalli, 2012, Problematic customers and turnover intentions of customer service employees, Journal of Services Marketing, 26/7, pp 551- 559

Rubin M.D. "Creating Customer-Oriented Companies". Adlittle Co. 5 November 2015. [Online].http://www.adlittle.com/uploads/tx_extprism/1997_q4_01-11.pdf.

Russo ,Marcello ., Filomena Buonocore, 2012, The relationship between work-family enrichment and nurse turnover, Journal of Managerial Psychology, Vol. 27 No. 3, pp. 216-236. 
Sani, A. (2013). Role of Procedural Justice, organizational commitment and job satisfaction on job performance: the mediating effects of organizational citizenship behavior. International Journal of Business \& Management, 8(15), 57- 67.

Shreya Garg, Rajib Lochan Dhar, (2014), Effects of stress, LMX and perceived organizational support on service quality: Mediating effects of organizational commitment, Journal of Hospitality and Tourism Management 21, 64-75.

Song ,Hak Jun, Hye-Mi Lee, Choong-Ki Lee \& Su-Jung Song (2015) The Role of CSR and Responsible Gambling in Casino Employees' Organizational Commitment, Job Satisfaction, and Customer Orientation, Asia Pacific Journal of Tourism Research, 20:4, 455-471

Song ,Hak Jun, Hye-Mi Lee, Choong-Ki Lee \& Su-Jung Song (2015) The Role of CSR and Responsible Gambling in Casino Employees' Organizational Commitment, Job Satisfaction, and Customer Orientation, Asia Pacific Journal of Tourism Research, 20:4,pp: 455-471.

Spagnoli, P., A. Caetano, S.C. Santos." Satisfaction with job aspects: Do patterns change over time?", Journal of Business Research, 2012. 65(5): 609-616.

Suleiman, M. A. \& Djouhara, A. M. A. (2011). "The impact of internal marketing on commercial banks' market orientation", International Journal of Bank Marketing, 29 (4), pp. 308-332.

Suliyanto, S., and Rahab, R. (2012). "The Role of Market Orientation and Learning Orientation in Improving SMEs Performance ". Asian Social Science, 8 (1).

Tepret, Nagihan Yildiz., Tuna, Kadir., (2015)," Effect of Management Factor on Employee Job Satisfaction: An Application in Telecommunication Sector ", Procedia - Social and Behavioral Sciences $195,673-679$.

Theoharakis etal , (2008), " Customer Orientation and innvativeness : Differing roles in new and Old Europ", Intern . j.of Research marketing, vol . (25), pp. 69-79.

Thomas W.H. Ng, (2015), " The incremental validity of organizational commitment, organizational trust, and organizational identification", Journal of Vocational Behavior 88, pp:154-163.

Wright, O. \& Grace, A. (2011). "Trust and commitment within franchise systems: An Australian and New Zealand perspective”, Journal of Marketing and Logistics, 23 (4), pp. 486-500.

Yusof, Jamaliah Mohd(2015)" Customer's Loyalty effects of CSR Initiatives " Procedia - Social and Behavioral Sciences 170,pp: $109-119$. 